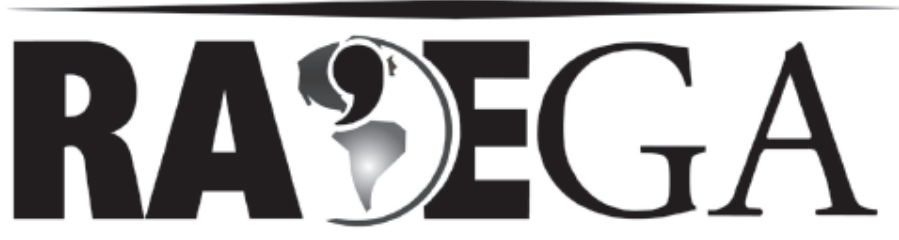

O ESPAÇO GEOGRÁFICO EM ANÁLISE

\title{
OPERÁRIO FERROVIÁRIO ESPORTE CLUBE: PATRIMÔNIO CULTURAL DE PONTA GROSSA
}

\section{OPERÁRIO FERROVIÁRIO ESPORTE CLUBE: CULTURAL HERITAGE OF PONTA GROSSA}

\author{
Edvanderson Ramalho dos Santos ${ }^{1}$ \\ Leonel Brizolla Monastirsky ${ }^{2}$
}

\section{RESUMO}

O presente artigo avalia como uma equipe de futebol centenária, o Operário Ferroviário, pode configurar-se como patrimônio cultural. Equipe nascida da família ferroviária, o Operário, ao longo de um século, acumulou diversos simbolismos e traços culturais peculiares. Foram diversas as modificações sociais, espaciais e culturais que o Operário contribuiu no cotidiano da sociedade e do espaço de Ponta Grossa. Sendo assim, o Operário constitui-se num importante elemento no processo de criação e manutenção da identidade local.

Palavras Chaves: Geografia Cultural; Patrimônio Cultural Intangível; Futebol; Memória; Cidade.

\section{ABSTRACT}

This article examines how a century-old football team, the Operário Ferroviário, can configure itself as a cultural heritage. Team born of the family railway, the Operário, over a century, has accumulated many unique cultural traits and symbolism. There were several social changes, spatial and cultural factors that contributed to the Operário in everyday society and the space of Ponta Grossa. Thus, the Operário constitutes an important element in the process of creation and maintenance of local identity.

Key-Words: Cultural Geography; Intangible Cultural Heritage; Soccer; Memory; City.

\footnotetext{
${ }^{1}$ Licenciado em Geografia. Mestrando em Educação pela Universidade Estadual de Ponta Grossa - PR. eddieuepg@hotmail.com

${ }^{2}$ Doutor em Geografia pela Universidade Federal de Santa Catarina. Docente na Universidade Estadual de Ponta Grossa - PR. leonel@uepg.br
} 


\section{Introdução}

Este artigo tem por objetivo analisar a representatividade de um clube de futebol centenário perante a sociedade. Avalia-se como uma equipe de futebol - o "Operário Ferroviário" - pode, através da sua presença, atividades e simbologia, configurar-se como um patrimônio cultural.

O Operário Ferroviário Esporte Clube foi fundado em 1912 e a sua história, que é contada juntamente com a história da ferrovia em Ponta Grossa $(P R)$, é formada com expressiva carga de simbologia e mitificação. O seu estádio - Germano Krüger - que fica próximo às instalações da ferrovia, é um "lugar-distinto", tanto por se caracterizar como a principal arena de espetáculos futebolísticos da região como também por ser um lugar de memória.

Conhecido carinhosamente como "Fantasma da Vila", essa agremiação possui representatividade tão significativa para Ponta Grossa e região que até mesmo quem declara não gostar de futebol sente a sua presença no cotidiano social. Sendo assim, ao se considerar a genealogia e a trajetória histórica do Operário Ferroviário; a importância da sua presença na cidade enquanto um equipamento urbano e social; a carga simbólica junto à sociedade e seus torcedores, estudar um time de futebol torna-se um interessante tema de pesquisa para a Geografia Cultural.

Fundamenta a hipótese inicial, que sugere a categorização do "Operário Ferroviário" como um patrimônio cultural, quatro premissas básicas: a) a sua história centenária enquanto agremiação esportiva; b) a sua trajetória histórica associada à história da ferrovia em Ponta Grossa; c) o acervo material e intangível do clube que se caracteriza como patrimônio cultural e d) o fato do Operário ser o representante da cidade nos campeonatos de futebol profissional.

O ponto de partida desta análise considera o significado que a equipe tem com a sociedade no tempo presente, ou seja, uma equipe de futebol que representa a cidade nos campeonatos paranaenses e brasileiros. A sociedade, especialmente os torcedores, deseja ser reconhecida através de uma equipe que participe positivamente nos torneios que compete - essa é uma 
circunstância reiterada em várias cidades e países, especialmente com a atual importância com que os jogos de futebol são reproduzidos na mídia.

Assim sendo, a trajetória da pesquisa parte do tempo presente, mas busca as informações necessárias do passado para compreender o contexto da sua construção histórica - um argumento ultimamente ignorado quando se efetuam análises sobre o espaço urbano e seus equipamentos sociais. (SANTOS, 1992).

O estudo apresenta, portanto, duas frentes de análise sobre as simbologias de um clube de futebol (que associadas justificam a sua escolha): a representatividade enquanto uma equipe de futebol atuante $e$ a representatividade enquanto um patrimônio cultural histórico. O Operário Ferroviário além de apresentar simbologia própria (comum a certos times, secular e querido), apresenta ainda simbologia associada à ferrovia no Brasil pois é uma agremiação esportiva que surge da intenção dos trabalhadores ferroviários num período áureo da ferrovia brasileira. Assim, a interconexão do clube em tela com as ferrovias reforça a hipótese de sua configuração como patrimônio cultural.

Dessa forma, a presente pesquisa foca suas atenções sobre a construção simbólica e mitificada do fenômeno cultural Operário Ferroviário Esporte Clube, por vários sentidos, como patrimônio cultural de Ponta Grossa.

A cidade ferroviária de Ponta Grossa, local desta análise, situa-se na região denominada "Paraná Pioneiro" - centro-leste do estado do Paraná. Foi fundada em 1875 e teve sua origem no Tropeirismo e, posteriormente, seu crescimento se deu com o desempenho de entreposto comercial no processo de exportação de erva-mate e madeira. Esta função estratégica do comércio regional foi potencializada com a implantação da ferrovia no final do século XIX e com o sistema rodoviário a partir da primeira metade do século XX. Atualmente essa estrutura se mantém e está aperfeiçoada para 0 armazenamento, industrialização e comércio de produtos agroindustriais.

Para responder os problemas de pesquisa, baseou-se na pesquisaação. Melo Neto (2000) declara que é através dela que se torna possível à descoberta e o acesso a dados peculiares da realidade a ser pesquisada. Desta maneira, buscou-se uma convivência próxima com o objeto de estudo, através da participação à torcidas organizadas do clube, excursão a jogos em 
outras cidades e observações em dias de jogos junto a torcedores, entre outras ações. Estas iniciativas possibilitaram uma melhor interpretação qualitativa do objeto de pesquisa, ao passo que se adentrou no espaço vivido (CLAVAL, 2002) dos sujeitos relacionados ao Operário Ferroviário.

Para a coleta de dados usou-se diferentes métodos: a) aplicação de cem questionários a torcedores e simpatizantes do clube, com perguntas abertas e fechadas; b) seis entrevistas semi-estruturadas para obtenção das informações, das narrativas e da história oral (CASSAB, 2005) relacionadas à história e representatividade do Operário. Para escolha desses entrevistados, priorizou-se torcedores que tiveram uma relação significativa com o Operário no passado, ou seja, torcedores constantes, ex-diretores e ex-jogadores; c) pesquisa em redes sociais de depoimentos e opiniões de internautas sobre 0 Operário Ferroviário; d) observações diretas dos torcedores no estádio (comportamentos nos jogos e fora do estádio) e nas ruas da cidade; e) pesquisas bibliográficas sobre a história do futebol em Ponta Grossa e no Paraná.

Desta forma esta pesquisa pretendeu investigar um clube de futebol centenário que está associado a um dos principais patrimônios culturais do Brasil: a Ferrovia. Assim, priorizou-se uma análise sobre o prisma cultural, compreendendo a representatividade, as memórias, as narrativas e a força sócio-espacial que o Operário acumulou ao longo de sua história e vem influenciando na organização do espaço urbano da cidade de Ponta Grossa. Para dados sobre as conquistas e outras informações históricas sobre o Operário, consultar Ribeiro Júnior (2002 e 2004).

\section{A nova abordagem cultural em Geografia, patrimônio cultural e o espaço de representação do Operário Ferroviário}

O (re)conhecimento do Operário como patrimônio cultural utiliza-se de uma das correntes da Geografia Humana: A nova abordagem cultural em Geografia (CLAVAL, 2002), que procura compreender o espaço a partir da dimensão cultural e as espacialidades geradas por tal dimensão (CORRÊA e ROSENDAHL, 2003). Esta abordagem analisa o espaço geográfico tanto do ponto de vista da materialidade quanto de seus elementos intangíveis, procurando compreender o sentido que as pessoas dão a sua existência e aos 
seus espaços de vivência (CLAVAL, 2002) e, complementando, a consideração de manifestações populares como ações e elementos culturais (CORRÊA, 1995).

Este é o caso do Operário Ferroviário, que através de seu estádio Germano Krüger -, torcedores se reúnem e fazem dessa materialidade um espaço especial, lugar de representações, de rituais, cerimônias, paixões, decepções e outros sentimentos que ali emergem.

Sendo assim, o espaço gerado por esse contexto é o espaço vivido. "O espaço é uma experiência contínua, egocêntrica e social, um espaço de movimento e um espaço vivido (...) que se refere ao afetivo, mágico e ao imaginário" (HOLZER, 1992, p. 440). Assim, o sujeito que freqüenta o estádio e vivencia as espacialidades geradas por uma partida de futebol, faz desse espaço uma vivência única e peculiar.

Além dessas relações que ocorrem no tempo presente, o espaço também é um local de memória, formado por elementos do passado. E é justamente essa junção de manifestações ocorridas no presente e o legado histórico que o estádio e, principalmente, o clube apresentam, que permite considerá-los patrimônios culturais.

Há uma trajetória histórica e uma composição mnemônica. A história e a memória de um espaço por sua genealogia, e o resultado da contínua relação desse espaço com a sociedade. E esse espaço associa-se à sociedade através da memória e destaca-se no meio urbano, especialmente por apresentar um suporte patrimonial - seja ele material ou intangível.

Sant'ana (2000) declara que a construção do direito à cidade e a luta pela sua melhoria se dá quando o cidadão se identifica com a mesma. E essa identificação segundo Fenelon et. al. (2004) ocorre quando a memória individual se reconhece na memória coletiva - o que proporciona ao indivíduo a sensação de aceitação e participação social.

As discussões a respeito do patrimônio cultural e da memória são pertinentes devido à ampliação das relações estabelecidas com a cultura na chamada era da indústria cultural e da mundialização cultural. Há um paradoxo, um conflito entre o velho e o novo, entre a ordem herdada e a ordem projetada (SOJA, 1993), sobre a valorização/participação da história na cultura - por desdobramento: da memória social e do patrimônio cultural. 
Outro ponto importante que sustenta as bases teóricas da pesquisa é a respeito do futebol. Por muito tempo esse esporte foi visto como "ópio do povo" - inclusive por intelectuais de esquerda do começo do século XX que, segundo Eduardo Galeano (2004), desqualificavam o futebol por contribuir com 0 atrofiamento da consciência operária e por ser um campo com simbolismos, paixões, afetividades e emoções. Dessa forma, por vezes o futebol foi aproveitado para ações políticas e ideológicas.

Por outro lado, vários geógrafos culturais vêm destacando a relevância social do futebol e as complexas relações desse com a produção e transformação do espaço e a cultura.

Campos (2006) expressa esse quadro ao destacar que o futebol é um elemento central da cultura brasileira e que colaborou na construção da identidade nacional. $\mathrm{O}$ autor afirma que o futebol transcende a sua qualidade esportiva, tornando-se um importante elemento sociocultural espacial em muitos países, como é o caso brasileiro, sendo possível e necessário seu estudo pela ciência geográfica.

Logo, o futebol além de ter uma grande magnitude na sociedade contemporânea, é um ativo produtor de espacialidades (CAMPOS, 2008), territórios e disputas territoriais nas cidades (GOMES, 2002).

Nos dias em que ocorrem partidas de futebol, as cidades passam por uma verdadeira re-territorialização promovida pelos torcedores. Assim, o espaço urbano torna-se objeto de apropriação das torcidas. Unidos em grupos, os torcedores tendem a não respeitar as ordens vigentes, ocasionando uma disputa territorial pelo espaço urbano, principalmente quando na cidade se tem dois clubes rivais (como aconteceu com a cidade de Ponta Grossa até a década de 1970, quando as torcidas do Operário Ferroviário e do Guarani Esporte Clube teatralizavam arenas territoriais de combate no campo, nas arquibancadas e nas ruas). Assim, por conta do futebol, a cidade passa a participar de seu circuito simbólico, sobreposta pela geopolítica das rivalidades. (GOMES, 2002).

Já Campos (2006 e 2008) propõe o conceito de espaço de representação do futebol. Embasado em leituras de Lefebvre (1991) e Gil Filho (2003), o autor salienta que o espaço é formado e produzido por três instâncias coexistentes e interdependentes, que se pode denominar de trialética do 
espaço. Essa tríade é formada pela prática espacial, a representação do espaço e o espaço de representação. Destas instâncias espaciais, o futebol estaria mais ligado ao espaço de representação, já que este corresponde à instância simbólica da espacialidade, onde o ser humano se auto-apresenta a fim de buscar seu prazer e autenticidade, sendo ligado às artes e manifestações culturais.

Shields ${ }^{3}$ (Citado por CAMPOS, 2008, p. 253) declara que é através do espaço de representação que se dão as experiências plenas do espaço vivido e que o ser humano se realiza como "pessoa total". Desta maneira, o espaço de representação é o local aonde as pessoas "fogem" da rotina e da cotidianidade. É o lugar para o prazer, para desestressar, para se divertir, mas também para subjugar o adversário. Portanto o estádio Germano Krüger em dias de jogos do Operário é um exemplo de espaço de representação.

Eu vou ao estádio ver a festa da torcida, tira o stress (Alexandre, questionário, junho de 2010).

Particularmente eu gosto do ambiente de um estádio de futebol. $\mathrm{O}$ barulho da torcida, o cheiro da comida. É algo único. (Márcia Saab, questionário, junho de 2010).

A história da propagação do futebol no Brasil associa-se a história da implantação da ferrovia a partir da metade final do século XIX. As ferrovias tiveram papel crucial, pois os engenheiros ferroviários e outros trabalhadores ingleses que vieram ao Brasil, na construção das primeiras estradas férreas, contribuíram para a disseminação do esporte no país.

Estes estrangeiros foram os primeiros a formar equipes locais e praticar o novo esporte, que era considerado pela população mais tradicional como um "um jogo de loucos" (GALEANO, 2004). Mas não demorou muito e o futebol caiu no gosto popular e ganhou traços e contribuições únicas da cultura brasileira.

No Brasil foi comum a criação de equipes de futebol por ferroviários muitas equipes que foram criadas apenas para as confraternizações em finais de semana se tornaram clubes oficiais. Arnoldo Bach (2008) cita mais de 80

\footnotetext{
${ }^{3}$ SHIELDS, R. Lefébvre, love \& struggle: spatial dialetics. Londres: Routledge, 1999.
} 
clubes profissionais de futebol criados por ferroviários nos estados brasileiros que tiveram implantada a rede ferroviária.

Vale lembrar que, como demonstra Monastirsky (1997 e 2006), a ferrovia é um patrimônio cultural do Brasil e, especificamente, das cidades ferroviárias, como o caso de Ponta Grossa. Esta constatação, que a princípio pode ser considerada de notório saber, é confirmada através da associação de análises sobre a ferrovia a partir da sua importância econômica, social e cultural; da sua participação na integração territorial; na organização do espaço urbano das cidades ferroviárias; da sua representatividade simbólica perante a sociedade e por ela estar presente, de maneira significativa, na memória de muitos indivíduos (e seus descendentes) que viveram os anos "áureos" da ferrovia.

Todavia, como ocorre em muitas cidades ferroviárias do Brasil, o patrimônio cultural ferroviário sofre o descaso dos poderes públicos e das instituições de transporte ferroviário que deveriam preservar esse patrimônio: a Rede Ferroviária Federal Brasileira SA e a América Latina Logística (empresa que cuida da estrutura ferroviária no Paraná, pós-privatização). Assim, muito desse patrimônio já foi demolido, abandonado à ação do tempo ou descaracterizado por mau uso.

Justificado a importância da preservação desse patrimônio cultural, a valorização do Operário Ferroviário torna-se ainda mais relevante. Por ser fruto das ferrovias, o clube em tela, ainda nos dias de hoje, carrega traços e características que remetem diretamente a memória ferroviária. Assim, o Operário ao fazer parte da simbologia ferroviária, é um dos patrimônios culturais da ferrovia. Portanto, preservar e valorizar o Operário Ferroviário Esporte Clube é também preservar a memória ferroviária.

\section{Operário Ferroviário Esporte Clube: Patrimônio Cultural}

O Operário Sport Club (primeira denominação) foi fundado em 1912, por trabalhadores ferroviários que trabalhavam nos escritórios e oficinas da Rede Viação Paraná - Santa Catarina, em Vila Oficinas, Ponta Grossa (PR). (RIBEIRO JUNIOR, 2002). (Fotografia 01). 


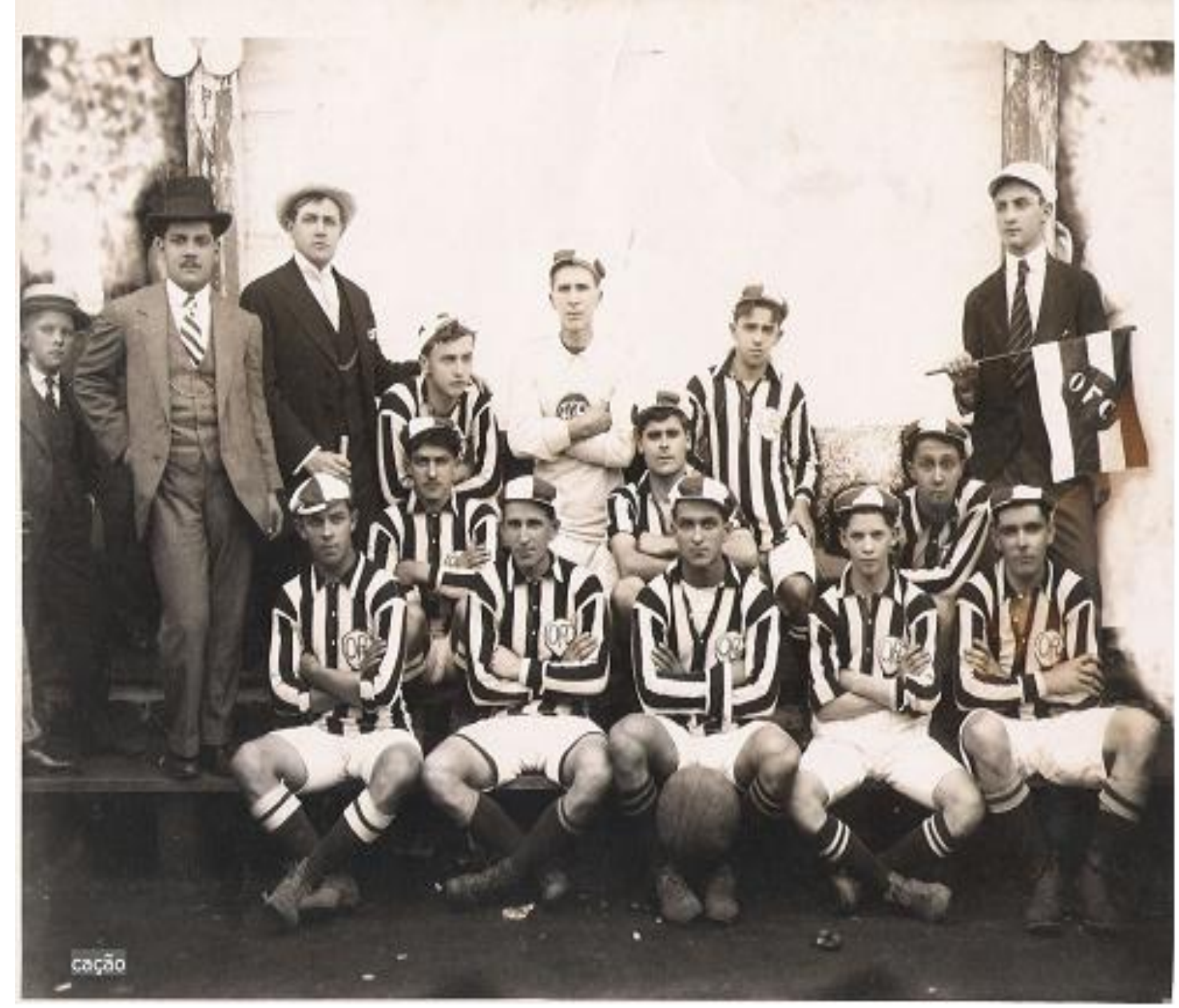

Fotografia 01: Equipe do Operário em 1916. Esta é uma das primeiras escalações da equipe dos ferroviários, o Operário Sport Club, em 10/09/1916. Fonte: Ribeiro Júnior (2002).

O clube já surgiu com simbolismos. Uma toponímia com uma classe que era bastante valorizada no início desse século: o trabalhador ferroviário. Através do nome do clube e a data da fundação, havia a intenção de se constituir uma bandeira dos operários (a data de fundação ficou convencionada para o dia primeiro de maio - dia do trabalhador). Já a escolha das cores (preto e o branco) foi uma alusão tanto aos negros quanto aos brancos da população brasileira, pois se vivia um período que muito se discutia sobre as políticas racistas e a participação de negros nas equipes de futebol - nessa época apenas o Vasco da Gama (RJ) permitia jogadores humildes e de pele negra em seus plantéis. (RIBEIRO JUNIOR, 2004). (Figura 01). 


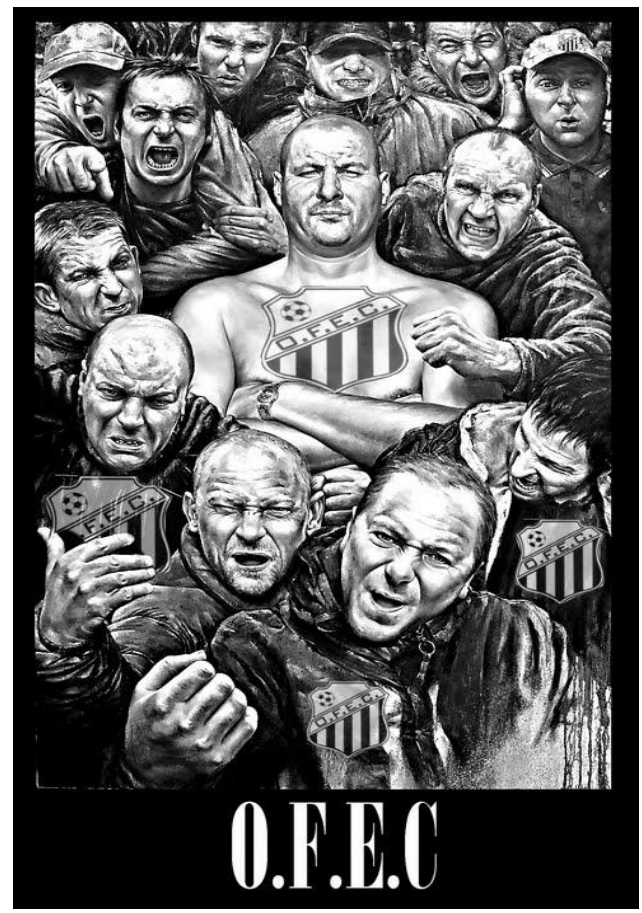

Figura 01: Montagem de "operários ferroviários". Feita por torcedores do Operário Ferroviário em homenagem a classe operária, a montagem faz alusão a torcedores tipicamente "graxeiros" e proletários. Fonte: Montagem produzida pelo torcedor Ricardo Loreno. (2010).

É do começo do século também que surgiu o apelido de "fantasma" ao Operário, que depois se tornou um dos principais símbolos do clube (Figura 02). Este apelido surgiu devido às exibições do Operário contra as equipes de Curitiba que vinham jogar em Ponta Grossa e, muitas vezes, eram surpreendidas. A imprensa curitibana da época alegava que esses resultados só poderiam ser obras de fantasmas.

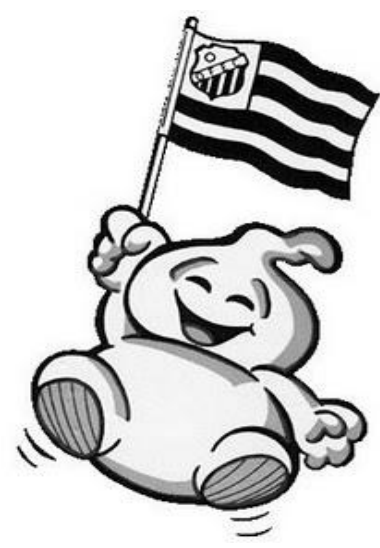

Figura 02: Mascote do Operário Ferroviário: o fantasma. Criação do chargista Ireno José Guimarães, o fantasma aparece nesse desenho simpático, alegre e sorridente, empunhando a bandeira do Operário Ferroviário. Fonte: Osni Gomes (2010). 
A lenda do "Fantasma" é uma das representações que o torcedor operariano e o cidadão pontagrossense muito consideram - notadamente em função da postura tendenciosa da imprensa paranaense com relação às equipes da capital. Tanto é assim que uma das torcidas organizadas se chama "Trem Fantasma" e a mascote aparece em diversas músicas que a torcida canta no estádio. É comum presenciar esses "fantasmas" em jogos do Operário Ferroviário. (Fotografia 02).

Todos, sem exceção deram o sangue para mostrar que o Interior ainda é forte, ainda pode engrossar o caldo dos times da capital. Agora o sentido da palavra fantasma mais do que nunca faz sentido prá mim e prá muitos operarianos. O time jogou muito, confesso que me emocionei ao ver o $2^{\circ}$ gol do nosso glorioso alvinegro... (...) Vendo a arrogância de torcedores da capital, que apostavam em goleada(...) (Willian Uczak, declaração após o jogo entre Operário e Atlético-PR em abril de 2010).

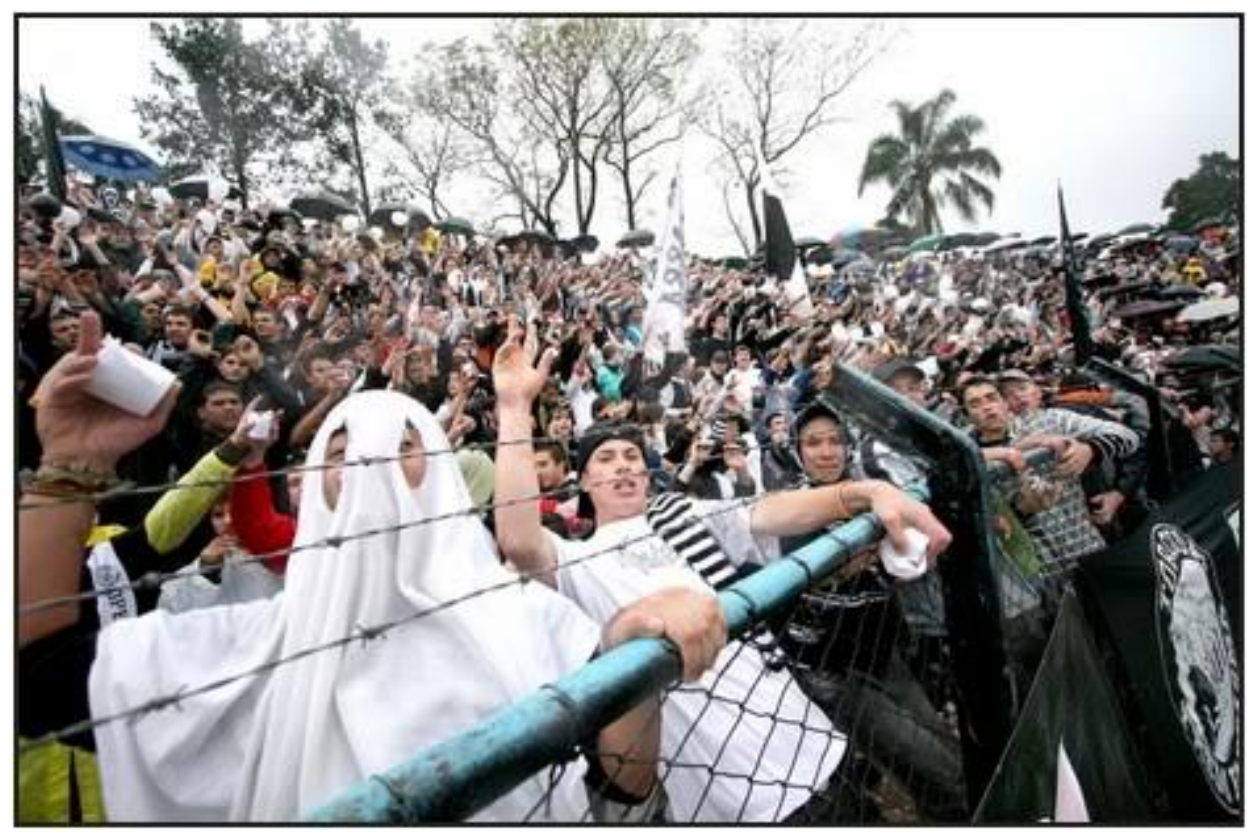

Fotografia 02: Torcedor fantasiado de fantasma. Ver torcedores de fantasmas é uma cena comum no estádio Germano Krüger. Nesta foto, o fantasma faz a festa e vibra na curva do diabo, como é chamada a parte sudeste do estádio. Fonte: Thiago Moro (2009).

Durante as décadas de 1950 até 1970, o Operário viveu uma das fases mais vitoriosas de sua história, porém, a partir dessa época o clube entrou em crise, que somente foram sanadas no ano de 2004 - quando a equipe retornou ao cenário profissional do campeonato paranaense e recentemente a série $D$ do Campeonato Brasileiro e também a Copa do Brasil. 
A união que o Operário causou a cidade de Ponta Grossa, principalmente na torcida pela busca pelo acesso à elite do futebol estadual (que durou seis anos - de 2004 até 2009) foi algo incomparável. O Operário esteve na moda, nas manchetes dos jornais e nas reportagens na TV. As pessoas vestiam a camisa do clube pelas ruas da cidade, registravam-se recordes de público no estádio e o Operário era assunto em centenas de rodas de conversas. O Operário Ferroviário confirmava ser uma das principais marcas da identidade do "ser pontagrossense" e um dos principais símbolos da territorialidade local. (Fotografia 03).

Mas isso que aconteceu agora, ano passado no dia que o Operário voltou a Série A do paranaense, foi marcante! Isso nunca tinha acontecido na história de Ponta Grossa, foi marcante.... Debaixo de Chuva e o pessoal pulando e gritando, Ponta Grossa unida ali na rua por uma causa, foi emocionante aquilo... E hoje criou-se esse estigma em torno do Operário. Essa paixão aflorou de um modo mais forte e as comemorações são maiores, como a do ano passado que chovendo (...) coisa de louco aquilo, jamais vista... (Risos). (Diomar Guimarães, entrevista julho de 2010).

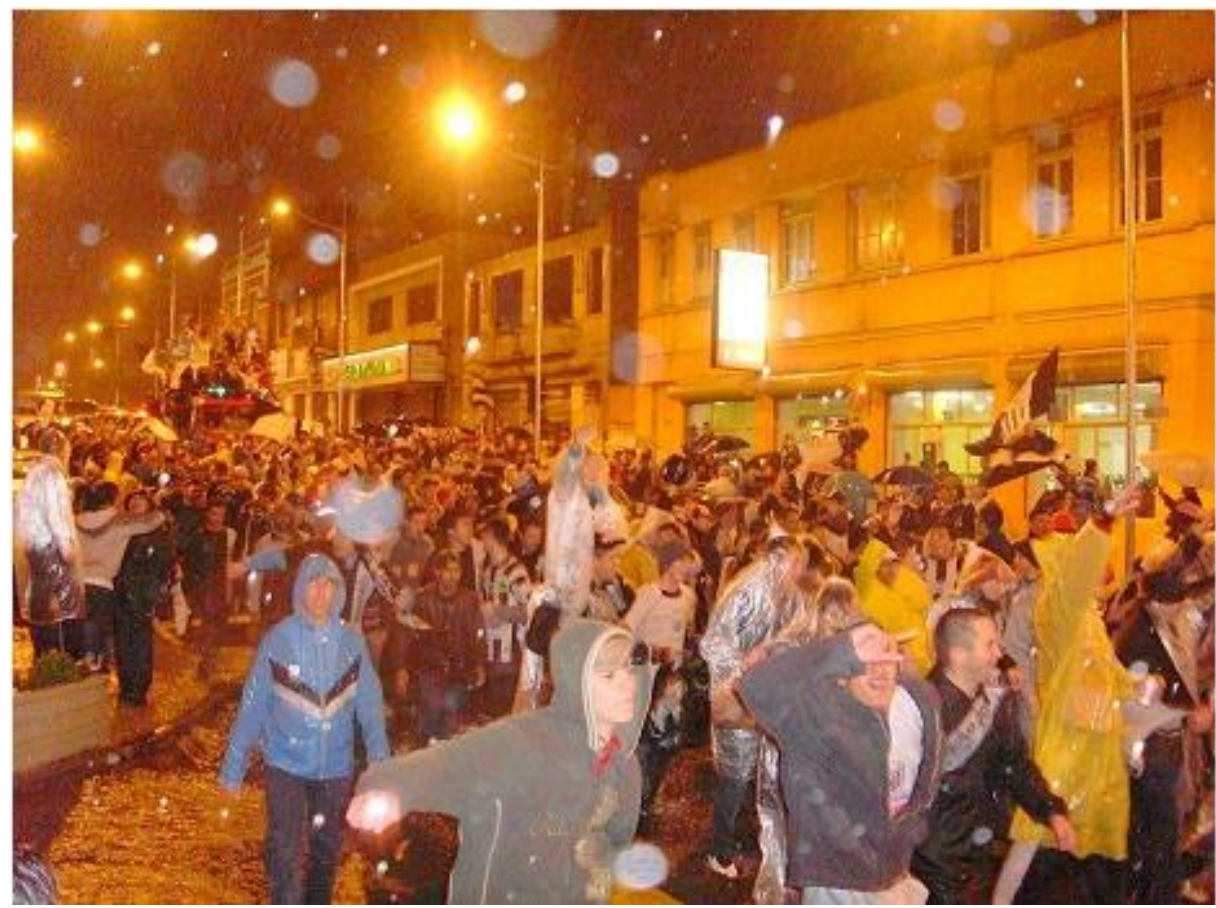

Fotografia 03: Comemoração do acesso a primeira divisão do campeonato paranaense na Avenida Vicente Machado. A comemoração do acesso rumou noite adentro, tomando as principais avenidas da cidade de Ponta Grossa. Por horas, o torcedor debaixo da chuva, pulou, gritou e festejou o tão sonhado acesso a divisão principal paranaense. Avenida Vicente Machado, 26 de julho de 2009. Fonte: Thiago Moro (2009). 
Embora o Operário Ferroviário se caracterize como uma equipe de futebol e um patrimônio cultural, essa dualidade nem sempre é simultaneamente reconhecida por todos. Todavia, essas duas frentes de representações ampliam a parcela da sociedade que exige a preservação desse patrimônio. Além daquelas pessoas que compreendem a necessidade da manutenção da história, há aqueles que, mesmo muito mais ligados ao futebol, contribuem para a preservação da cultural local.

Além de tudo isso, o Operário ainda carrega a simbologia da ferrovia em Ponta Grossa, contribuindo para preservação de sua memória na cidade. Essa preocupação pela preservação do patrimônio ferroviário pode ser percebida através de uma torcedora, quando questionada sobre uma possível mudança do nome da equipe (tema discutido por algum tempo entre os torcedores). Ela declarou que Ponta Grossa só cresceu em função da ferrovia e que ter uma equipe com esse nome (Operário Ferroviário Esporte Clube) é muito importante para a cidade e para a manutenção da sua história. Preocupada com as ações da prefeitura municipal, que é omissa com relação á preservação do patrimônio histórico e cultural da cidade, a entrevistada enaltece a importância do nome da equipe, do nome da principal torcida organizada - "Trem Fantasma"- e da localização do estádio no bairro de Oficinas. "(...) por isso acho que não pode mudar o nome. Tem que manter a identidade para os mais novos saberem da importância que tiveram os trens para a cidade" (Marcia Saab, entrevista realizada em junho de 2010).

Essa pesquisa ainda apontou que no questionário e nas entrevistas, $80 \%$ dos entrevistados (total de sujeitos de pesquisa: 106) associam o Operário Ferroviário à ferrovia. E essa associação sempre esteve presente nas manifestações populares. Durante a década de 1960, alguns torcedores chegaram a equipar uma caminhonete de "trem fantasma" que apitava, soltava fumaça e desfilava antes dos jogos e após as vitórias e conquistas do Operário Ferroviário (Fotografia 04). 


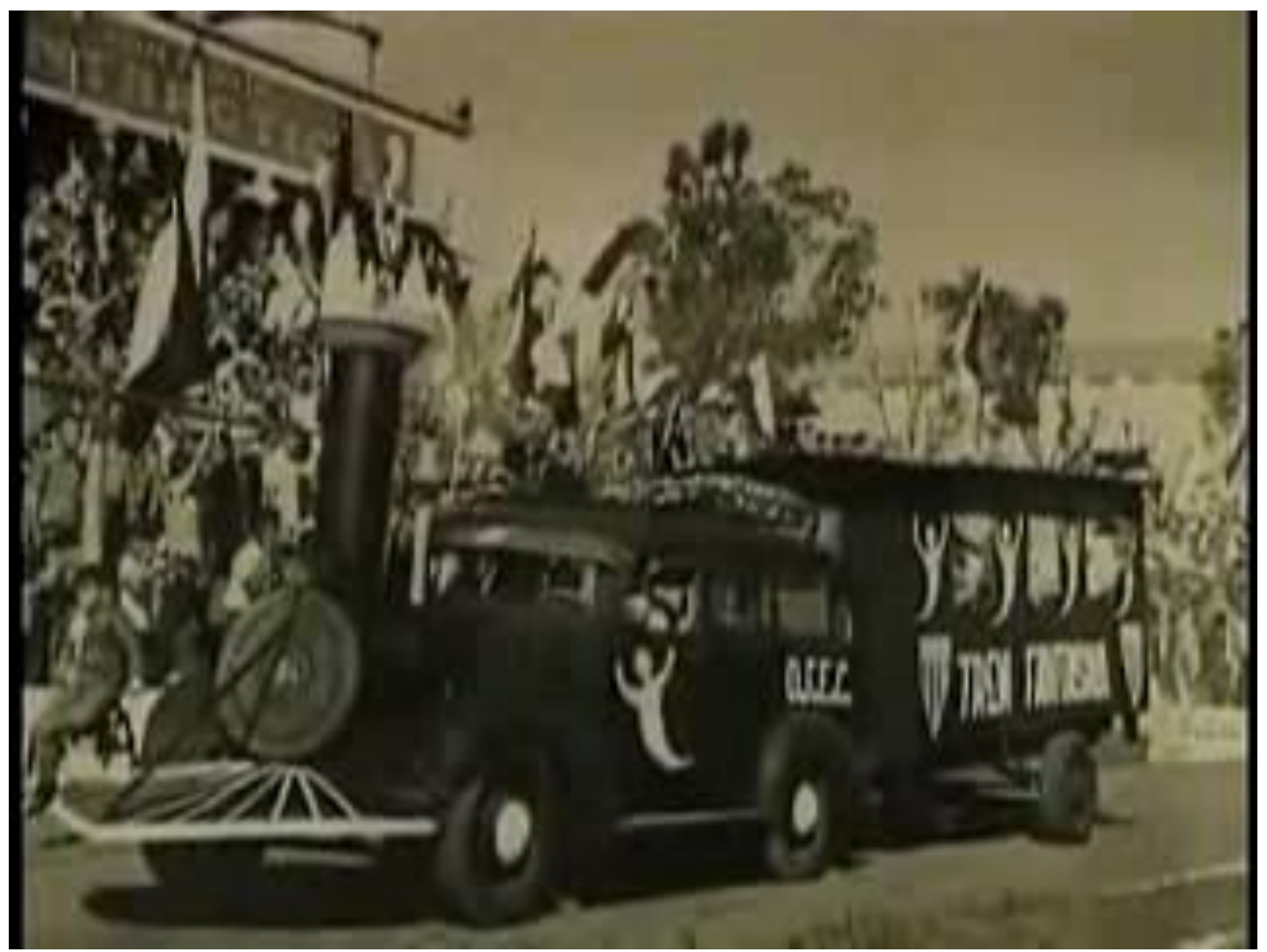

Fotografia 06: Carro alegórico "trem fantasma". Pertencente a um torcedor do Operário Ferroviário da década de 1960, que representa uma Maria Fumaça. Fonte: Ribeiro Junior, 2002.

\section{Considerações Finais}

A partir de 2009, o Operário Ferroviário melhor organizado e com equipes competitivas, passou a ser um dos focos da imprensa local e estadual, os torcedores voltaram a vestir as cores do time. Com o estádio cheio o clube passou a ser um dos assuntos mais comentados nas rodas de conversas. $O$ Operário voltava a ser uma das principais marcas da identidade local.

Essa paixão reflete também o desejo dos torcedores e simpatizantes pelo jogo de futebol de terem uma equipe para torcer e avançar nos campeonatos que disputa. Há um apelo mundial e, especialmente brasileiro, com relação ao futebol e aos desdobramentos das suas simbologias. 0 torcedor do Operário, ao acompanhar pela TV ou pela internet as grandes movimentações do futebol pelo mundo, também quer viver essas emoções: ir ao estádio, gritar, pular, fazer parte de torcidas organizadas, criar canções de apoio - uma forma de identidade, nesse mundo competitivo de representações. 
Ao longo do século $X X$ - especialmente com a mundialização cultural e com a magnitude que o futebol atingiu na sociedade global, passou a ser de fundamental importância para as cidades possuir um clube de futebol que as represente, que as divulgue e que vençam os embates esportivos.

Portanto, é através do Operário Ferroviário Esporte Clube que muitos cidadãos se sentem realizados. O Operário representa o cidadão e o cidadão se sente representado por ele. Santana (2000) declara que os cidadãos só lutam por sua cidade quando se sentem unidos por ela, e essa união o Operário Ferroviário ajuda a afirmar.

Desta forma, o Operário Ferroviário Esporte Clube é um patrimônio cultural em vários sentidos. Um clube de futebol que surgiu com os ferroviários e que aos poucos ganhou toda a cidade.

O Operário, ao longo de um século, acumulou diversos simbolismos e traços culturais peculiares. Foram diversas as modificações sociais, espaciais e culturais que o Operário contribuiu no cotidiano da sociedade de Ponta Grossa, constituindo-se num importante elemento no processo de criação e manutenção da identidade local.

Além de entender o Operário como um patrimônio cultural, a pesquisa permite analisar o funcionamento das hierarquias simbólicas entre as cidades. No caso de Ponta Grossa, é possível afirmar que existe uma hierarquia entre as cidades em função de possuir ou não equipamentos de infraestrutura de desenvolvimento econômico (ferrovias, rodovias, portos, indústrias, aeroportos, tecnologia, etc.). Mas também existe outro indício dessa hierarquização social, mais simbólica, que é o fato da cidade possuir uma equipe de futebol nas principais divisões do esporte estadual e nacional.

\section{Referências}

BACH, Arnoldo Monteiro. Trens. Palmeira-PR, 2008.

CAMPOS, Fernando Rosseto Gallego. A construção do espaço de representação do futebol, em Curitiba-PR. 2006, 239 p. Dissertação (Mestrado em Geografia). Programa de Pos-Graduação em Geografia, Universidade Federal do Paraná, Curitiba, 2006. Disponível em: < http://dspace.c3sl.ufpr.br/dspace/handle/1884/4120>. Acesso em 08 de nov. 2009. 
Geografia e futebol? Espaço de representação do futebol e rede sócioespacial do futebol. Terr@Plural, Ponta Grossa, 2 (2): 249-265 , jul./dez., 2008. Disponível em: $<$ http://www.revistas.uepg.br/index.php?journal=tp\&page=article\&op=download \&path\%5\%5D=404\&path\%5B\%5D=666>. Acesso em: 27 out. 2009.

CASSAB, Latif Antonia. História Oral: miúdas considerações para a pesquisa em Serviço Social. Serviço Social em Revista, www.ssrevista.uel.br, v. 5, p. $5 / 2,2005$.

CLAVAL, Paul. A Geografia Cultural. Tradução de Luiz Fugazzola Pimenta e Margareth de Castro Afeche Pimenta. Florianópolis: UFSC, 2002.

CORRÊA, Roberto Lobato. A dimensão cultural do espaço: Alguns temas. Espaço e Cultura, Rio de Janeiro, UERJ, ano 1, out. 1995. Disponível em $<$ http://www.nepec.com.br/2lobato.pdf >. Acesso em 08 out. 2009.

; ROSENDAHL Zeny. (Orgs). Introdução à Geografia Cultural. Rio de Janeiro: Bertrand Brasil, 2003.

FENELON, Déa Ribeiro; MACIEL, Laura Antunes; ALMEIDA, Paulo Roberto de; KHOURY, Yara Aun. (Orgs.). Muitas Memórias, Outras Histórias. São Paulo: Olho D'Água, 2004.

GALEANO, Eduardo. Futebol ao sol e à sombra. Tradução de Maria do Carmo Brito e Eric Nepomuceno. Porto Alegre: L\&PM Editores, 2004.

GIL FILHO, Sylvio Fausto. Espaço de representação: epistemologia e método. ANPEGE, Florianópolis, 2003.

GOMES, Paulo César da Costa. O futebol e sua dimensão estética: Entre a geopolítica da bola e a geopolítica dos torcedores. In: A condição urbana. Rio de Janeiro: Bertrand Brasil, 2002.

HOLZER, Werther. A Geografia Humanista: sua trajetória de 1950 a 1990. Dissertação (Mestrado em Geografia). Departamento de Pós-graduação em Geografia da Universidade Federal do Rio de Janeiro, Rio de Janeiro, 1992.

LEFEBVRE, Henry. The production of space. Oxford: Blackwell, 1991.

MELO NETO, José Francisco de. Pesquisa-ação. Coletânea de Cultura e Consciência Social, N. 4, João Pessoa - PB, v. 1, n. 1, p. 65-72, 2000.

MONASTIRSKY, Leonel Brizolla. Cidade e ferrovia: a mitificação do pátio central da RFFSA, em Ponta Grossa (PR). Dissertação de Mestrado. Florianópolis: UFSC/CFH/PPGGeo, 1997.

Ferrovia: Patrimônio Cultural, estudo sobre a ferrovia brasileira a partir da região dos Campos Gerais (PR). Tese de Doutorado. Florianópolis: UFSC/CFH/PPGGeo, 2006. 
RIBEIRO JÚNIOR, José Cação. Operário o fantasma da vila. Ponta Grossa: UEPG, 2002.

. Futebol ponta-grossense: Recortes da História. Ponta Grossa: UEPG, 2004.

SANT'ANA, Marco Aurélio. Memória, cidade e cidadania. In: COSTA, Icléia Thiesen Magalhães; GONDAR, Jô (Orgs.). Memória e espaço. Rio de Janeiro: 7 letras, 2000.

SANTOS, Milton. Palestra de abertura da Semana de Geografia da UFSC, Florianópolis, 1992.

SOJA, Edward W. Geografias pós-modernas: a reafirmação do espaço na teoria social crítica. Rio de Janeiro: Jorge Zahar, 1993. 